\title{
THE IMPACT OF TRAUMATIC EXPERIENCES TO SEO JIN-WOO CHARACTER IN REMEMBER KOREAN DRAMA
}

\author{
Benazir Isna ${ }^{1}$, Dr. Bima Prana Chitra M. Hum ${ }^{2}$ \\ Fakultas Bahasa dan Komunikasi \\ Universitas Harapan Medan \\ Email: isnabena11@gmail.com
}

\begin{abstract}
The objective of this research are characterization of Seo Jin Woo, impact of traumatic experience to Seo Jin Woo, Psychoanalysis of Seo Jin Woo character and moral values presented in Remember drama. This research used descriptive qualitative research. The data of this research were script, character, and drama on Remember (2015) as the source of data. This research focuses on characterization of Seo Jin Woo Nurgiyantoro (1955), traumatic experience by Seo Jin Woo character based on DSM (1980), psychology of Seo Jin Woo character based on theory Sigmund Freud (1896), and moral values in drama Remember based on Hurlock, Elizabeth ( 1972:386).
\end{abstract}

Keywords: Characterization, Traumatic experience, Psychoanalysis, Moral

\begin{abstract}
Abstrak
Tujuan penelitian ini adalah untuk mengetahui karakterisasi Seo Jin Woo, dampak pengalaman traumatis terhadap Seo Jin Woo, Psikoanalisis karakter Seo Jin Woo dan nilai-nilai moral yang disajikan dalam drama Remember. Penelitian ini menggunakan penelitian deskriptif kualitatif. Data penelitian ini berupa naskah, tokoh, dan drama dalam Remember (2015) sebagai sumber data. Penelitian ini berfokus pada penokohan Seo Jin Woo Nurgiyantoro (1955), psikologi tokoh Seo Jin Woo berdasarkan teori Sigmund Freud (1896), pengalaman traumatis tokoh Seo Jin Woo berdasarkan DSM (1980), dan nilai-nilai moral dalam drama Remember based di Hurlock, Elizabeth (1972: 386).
\end{abstract}

Kata kunci: Karakterisasi, Pengalaman traumatis, Psikoanalisis, Moral 


\section{Introduction}

\subsection{Background of Study}

The literary work has its own definition taken from each different literature expert. According to Pradopo (1994: 26) the literary work is as the picture of the world and human life, the main criteria that is putted on the literary work is 'truth', or everything that wants to be pictured by the author. Through that process, the reader of their literary work will be able to catch the characteristic of the author related with the world around him/her. Types of literary works is prose, drama, poetry, novel, songs, etc. In this thesis reseacher want to describe about drama. A drama is defined as a piece of literature which the intended purpose is to be performed in front of an audience. Drama are written in the form of a script, and the story is told through the lines of the characters played by actors. In a drama there are many elements which build the unity of the whole story. One of the elements is a character. Character can be defined as any person, animal, or figure represented in a literary work.

Characterization is the characteristic of a characteristic of a character presented in a literary work.Characterization is the characteristic of a characteristic of a character presented in a literary work. According to (Nurgiyantoro, 1955), characterization is a figure or people's character who is put forward in narrative work which interpret by the readers having a moral quality and certain tendency through dialogues and their behavior. According to (Nurgiyantoro, 1955), characterization is a figure or people's character who is put forward in narrative work which interpret by the readers having a moral quality and certain tendency through dialogues and their behavior.

Traumatic Experience is unbearable situation that force our mind to rethink memory in the past. It is introduced by Sigmund Freud that a situation which happens in a short time, that "increase the strength of a given stimulus" which affecting someone to create fear abnormally. Traumatic experience has a close relation to psychological trauma.

The post traumatic syndrome resulting from combat is similar to rape or violent crime. (2005:146-147). His concept is developed by The American Psychological Association (APA) with a new term called PostTraumatic Stress Disorder. The information regarding to post-traumatic stress disorder symptoms are collected in Diagnostic and Statistical Manual of Mental Disorder (DSM) in the first publication at 1980. DSM is the manual used by psychiatrist and researchers to diagnose mental disorder.

Psychoanalysis is a method of medical treatment for those who suffer from nervous disorder which was proposed by Sigmund Freud in 1896, psychoanalysis is concerned with the concept of unconsciousness. According to Guerin, Labor, Morgan, Ressman, and Willingham The super-ego works as the boundary between the id and the ego. It works as a judgment between right or wrong and good or bad.

Moral is controlled by the moral concepts, the rules of moral to which the members of culture have become accustomed to and which determine the expected behavior pattern of all group members. Every society has values to arrange their life that contains some principles, ideas and standards (Hurlock, Elizabeth, 1972:386). In a literary work, moral value is like a theme which is expressed in the body of a story. A moral value is something that the researcher tries to convey to the readers. It is the knowledge to be presented in a story. In general, moral can be defined as the distinction between good and bad, right and wrong with regard to attitudes, behavior, character, etc (Nurgiyantoro,2002:172).

In the drama the main character is Soe Jin-Woo was depression because of his father Seo Jae-Hyuk became a rape and murder suspect which was not his father's did. He has the condition of "Hyperthymesia" which allows him to remember almost every day in perfect detail. To prove the innocence of his father, Jin-Woo becomes a lawyer. But his 
father died before he did it. He struggles to prove his father's innocence, but he begins to lose his memory due to Alzheimer's. He just remeber the memories about himself and his father only.

\subsection{Problems of the Study}

Based on background above, the problems can be formulated as follows:

1. How is Seo Jin-Woo's characterization in Remember Korean drama?

2. How do traumatic experiences impact to Seo Jin-Woo's personality?

3. What moral values can be achieved from Remember Korean drama?

\section{REVIEW OF LITERATURE}

\subsection{Theoretical Framework}

\subsubsection{Psychoanalytic Theory}

The Psychoanalytic Theory is the personality theory, which is based on the notion that an individual gets motivated more by unseen forces that are controlled by the conscious and the rational thought. According to Monte (1977), Psychoanalytic theories assume the existence of unconscious internal states that motivate an individual's overt actions.

As we know Psychoanalysis is a branch of science developed by Sigmund Freud and his followers, as a study of human psychological function and behavior. According Brenner (1969 :11), Psychoanalysisis a scientific discipline which was begun some sixty years ago by Sigmund Freud. What we call psychoanalytic theory, therefore, is a body of hypotheses concering mental functioning and development in a man..

In another side, according to Barry in Rahayu (1995: 96) stated that psychoanalysis itself form of therapy which aims to cure mental disorders. Psychoanalysis was developed by Sigmund Freud as a psychiatrist. Freud adduce that psychic life contains two parts that are conscious and unconscious.

\subsubsection{Structuralism}

Structuralism is a method of interpreting and analysing such things as language, literature, and society, which focuses on contrasting ideas or elements of structure and attempts to show how they relate to the whole structure. According to Abrams (1981: 87), in approaching a literary work, structuralist criticism stands free from poet, audience, and its environment. It describes the literary work as a self-sufficient object. What Abrams means by the self-sufficient object is a system which consists of inseparable interrelation elements.

The structure of literary works is also heading to the relationship among the elements. Each element can be very meaningful and important after having connection with the other elements as well as its contribution towards the story or play. Structuralism can be seen as one of literary approaches which give more attention on the relationship among the elements involving in a certain work. According to Hawkes (1978), structuralism is basically about how we see the world as a formative link not as a formative thing. An element in a system of structure will have a meaning after getting a link with the others. Basically the analysis of structuralism purposes to elaborate accurately the function and the relationship among the elements of literary works.

\subsection{Relevant Studies}

The several revelant studies with the researcher in analyzing the same topic about trauma in their work. However, each relevant studies finding has significant differences to this research.

The first research is The Analysis of Trauma in Staub's Novel "Scared To Death" thesis by Sulaeman form Universitas Islam Negri Alaudin Makasar (2014). In that research, he discusses the portrayal of post traumatic by two main character. The researcher describe how the two main character ways to heal Posttraumatic.

The second research is Post-Traumatic Stress Disorder Suffered by Katie in Nicholas in sparks' safe heaven thesis by Abdul Mufied Yasin Universitas Islam Negri maulana malik Ibrahim Malang (2016). In that research, he discusses symptoms and causes of the post 
traumatic and he also discusses about the impact of post traumatic the character.

The third research is A Psychological Analysis Of The Main Character In Marsiraji Thahir's Kabar Bunga journal by M. Afifulloh Universitas Bangka Belitung (2019). In that research, he discusses he female characters of the novel,her conflicts and its causes, and the impact of the conflicts experienced by the main character.

The similarity between this research and those relevant studies are analyzed about traumatic and psychology the character in literary works. Those thesis gave reseacher references in this paper to help analyze the characters in psychology aspect. The differences researcher and those thesis is the several theories, their using data from the novel to analyze the psychology the character and procedures to get the data for discussion with previous research.

\subsection{Conceptual Framework}

\subsubsection{Drama}

Drama is a type of literature that is written for the purpose of being performed in front of an audience. Abrams (1988:45), states that Drama is the literary form designed for performance in the theater, in which actors take roles of the characters, perform the indicated action, and utter the written dialogue.

This research, researcher uses data with korean drama. Now days korean drama is most popular in Indonesia. Korean drama phenomenon better known by the Korean Waves, is the popularity of Korean culture in other countries. This phenomenon provides the latest Korean entertainment, such as movies, dramas, music and so on. The term Hallyu itself, actually first originated from China. Korean drama refers to the Korean television drama created in the miniseries format. According Lee (2011: 86), The Korean wave refers to the significantly increased popularity of South Korean culture around the world; it is also referred to as hallyu (Korean drama), in the Korean language.

In theme, Korean dramas have in common with the other dramas. The plot tells the stories of romance, family and everyday life. Therefore, the audience is dominated by female, as written an article. According Ayu (2011: 4), Korean drama in the plot always describe or tell the dream of many young women, which had a lover that handsome, wellknown, respected, rich and full of affection that was delivered with very romantic with sweet words and behavior are highly desired by many young women.

The story of the drama may be a picture of our lives or the writer. So the audience can learn and take positive value from the story in the drama. Elements of Drama :

a. Plot

Plot, referring to the basic storyline of the play, is the structure of a play which tells what happens as the story goes. The plot structure can be divided into six stages: exposition, inciting incident, rising action, climax, falling action, and denouement.

b. Character

Characters are the people, or sometimes animals, subjected in the drama, and are portrayed by the actors and actresses in the play. They are one of the main components that move the action of the play forward. Characters can be categorized into three types according to the roles they play. The main character of the play is known as the protagonist.

c. Setting

The setting is the place, together with other conditions, such as time and the environment, involved in which the events occur. The setting in the drama can be presented through the visual element deals with the scenes, costumes and special effects used in it.

d. Theme

The theme refers to the message that is intended to be expressed through the story. In other word, it is the main idea or the lesson to be learned from the play. From experiencing a play and examining the various elements of a play we derive a sense of its significance and meaning. We use the word theme to designate the main 
idea or point of a play stated as a generalization.

e. Genre

Genre is the type of play. The examples of genre in which the play can be classified include tragedy, comedy, romantic, mystery, and historical play.

f. Conflict

Conflict is something that dramatic, referring to the struggle between two forces are balanced and imply action and retaliation. In modern drama the conflict centers round the philosophical beliefs that life is meaningful and the experience that such meaning does not really exist

\subsubsection{Characterization}

Characterization is the characteristic of a characteristic of a character presented in a literary work. According to (Nurgiyantoro, 1955), characterization is a figure or people's character who is put forward in narrative work which interpret by the readers having a moral quality and certain tendency through dialogues and their behavior.

According Seymour Chatman in his "Reading Narrative Fiction", (1993), characters are given traits by a process called characterization. They may be characterized in a variety of ways.

There are several ways that can be used by the author to describe the appearance, character or personality of these figures (Lubis, 1960: 18) :

1. Physical description

2. Portrayal of thought stream of conscious thought

3. Reaction to events

4. Direct author analysis

5. Discussion of environment

6. Reaction of others about to character

7. Conversation of other about character

\subsubsection{Traumatic Experience}

Psychological trauma makes a person would be a very severe stress. If the trauma is sustained, it will lead to disruption of one's soul. According to Bryant and Ehlers (2003: 45), psychological trauma is a type of damage to the psyche that occurs as a result of a traumatic event. Trauma comes in many forms, and there are vast differences among people who experience trauma.

There are several things that cause a person get a psychological trauma. It can be from the human error or natural disaster. The psychological trauma caused by human error such; sexual abuse, bullying, domestic violence, indoctrination and mechanized accidents (car, train, or plane crashes, etc), while the psychological trauma is caused by natural disaster such as earthquakes, volcanic eruptions, landslide, flash floods and etc. The individual experiences (subjectively) a threat to life, bodily integrity, or sanity. Thus, a traumatic event or situation creates psychological trauma when it overwhelms the individual's ability to cope, and leaves that person fearing death, annihilation, mutilation, or psychosis. The individual may feel emotionally, cognitively, and physically overwhelmed. The circumstances of the event commonly include abuse of power, betrayal of trust, entrapment, helplessness, pain, confusion, and/or loss (Pearlman \& Saakvitne, 1995: 60).

For Freud (1958), a trauma is retroactively induced when excess psychic excitations penetrate the ego defenses, and can be worked through in the analytic setting by binding the excess forces together. Psychological trauma is a type of damage to the psyche that occurs as a result of a severely distressing event.

Traumatic Experience is unbearable situation that force our mind to rethink memory in the past. It is introduced by Sigmund Freud that a situation which happens in a short time, that "increase the strength of a given stimulus" which affecting someone to create fear abnormally. According to Freud, traumatic experience causes post traumatic syndrome called shell shock or war neurosis. The term of shell shock or war neurosis is inherited from his patient who was a victim of World War I.

However, the post traumatic syndrome resulting from combat is similar to rape or violent crime. (2005:146-147). His 
concept is developed by The American Psychological Association (APA) with a new term called Post-Traumatic Stress Disorder.

According to APA, Post-Traumatic Stress Disorder is a part of anxiety disorder that is happened by extreme or memorable events cause to extreme psychological trauma followed by repeated emotional act. (1994:274) The information regarding to post-traumatic stress disorder symptoms are collected in Diagnostic and Statistical Manual of Mental Disorder (DSM) in the first publication at 1980. DSM is the manual used by psychiatrist and researchers to diagnose mental disorder.

\subsubsection{Characteristic of Post-Traumatic Stress Disorder}

According to DSM IV, there are four diagnostic symptoms of Post-Traumatic Stress Disorder:

\section{a. Exposure to Stressor}

According to Marshall, stress is a disparity between society's pressure to conform to extreme events with individual's capability to adapt to those events. In other words, stress is the result of individual's inability to adapt to the extreme events. Those extreme events are usually known as stressor. Stressor is an extreme event that can cause excessive stress (i.e threatened death, serious injury, or sexual violence). Meanwhile, exposure is the state of being exposed, in this case is related to stressor. The way, stressor is exposed are in the following:

1. Experiencing the traumatic event.

2. Witnessing the events as it experiences to other people.

3. Learning the traumatic event happened to a close family member.

\section{b. Re-experiencing of Event}

PTSD can be known as a fear of extreme memories of traumatic event that repeatedly experienced by someone. The following intrusion symptoms connected with the traumatic events such as:

1. Recurrent, involuntary, and intrusive memories (images or thoughts,)
2. Recurrent, distressing dreams are related to traumatic events.

3. Dissociative reaction such as; experiencing illusions or hallucinations, having flashback episodes).

\section{c. Avoidance}

People with PTSD commonly avoid some events related to traumatic experience. The avoidance occurred in the beginning after the traumatic events happened, as indicated by the following:

1. Making attemps to avoid images, feelings, or conversation that remembering one of the traumatic events.

2. Feeling fear, guilt, sadness, shame or confusion after the traumatic event occurred.

3. Shutting out the memories of painful periods and experiencing amnesia.

\section{d. Arousal}

Arousal is a state where nervous system is sensitive to an overwhelming trauma, so the traumatic experience becomes elevated in the worse way. The symptoms of arousal occurred in the beginning or worsening after the traumatic events such as:

1. Reckless or self-destructive behavior.

2. Irritability or outburst of anger.

3. Blackout in specific case such as; depersonalization and derealization.

4. Exaggerated startle response.

5. Difficulty concentrating.

\section{e. Duration}

The symptoms described above (Reexperiencing of Event, Avoidance, and Arousal) existsed longer than one month.

\section{f. Life Disrupted}

The disturbance causes distress or impairment in society. Schiraldi defines life disrupted as a PTSD symptom that can disturb life and relationship. It could be avoiding people, social situation and hostility or anger. (2009:12)

\subsubsection{Psychoanalysis}

Psychoanalysis is a method of medical treatment for those who suffer from nervous 
disorder which was proposed by Sigmund Freud in 1896, psychoanalysis is concerned with the concept of unconsciousness. The unconsciousness can be described as storehouse of painful experience, emotion, wound, fear, guilty desire and unresolved conflict we don't want to know about. In relation with literature, psychoanalysis introduces concept of unconsciousness with language. All creative works are product of the author's mind; either it is conscious or unconscious. Freud developed three elements of personality: id, ego and super-ego.

According to Guerin, Labor, Morgan, Ressman, and Willingham The super-ego works as the boundary between the id and the ego. It works as a judgment between right or wrong and good or bad. According to Guerin, Labor, Morgan, Ressman, and Willingham (2005 : 158), acting either directly or through the ego, the superego serves to repress or inhibit the drives of the id, to block off and thrust back into the unconscious those impulses toward pleasure that society regards as unacceptable, such as overt aggression, sexual passions, and the Oedipal instinct.

According Alwisol (2014: 15), the ego develops from the id so that people are able to handle reality, so the ego operates following the principle of reality. In line with this by Friest \& Feist (2010: 27), that the ego is governed by the principle of reality, which seeks to be a substitute for the pleasure principle of id.

\subsubsection{Moral values}

Moral is controlled by the moral concepts, the rules of moral to which the members of culture have become accustomed to and which determine the expected behavior pattern of all group members. Every society has values to arrange their life that contains some principles, ideas and standards (Hurlock, Elizabeth, 1972:386)

There are four major and specific categories of moral values proposed by Kinnier et.al.as follows:

1. Commitment to something greater than oneself
a. To recognize the meaning and purpose of one's existence
b. To seek truth
c. To seek justice

2. Self-respect, but with humbleness or respect to others, self-discipline, and acceptance of personal responsibility

a. To respect and care for one-self

b. To not exalt one-self, avoid greediness, and self-centeredness

c. To act with conscience

d. To accept responsibility of one's behavior

3. Respect and caring for others
a. To recognize the connectedness between all people
b. To serve and to be helpful to humankind and individuals
c. To be caring, respectful, compassionate, tolerant, and forgiving to others $d$. To not hurt others (do not murder, abuse, steal from, cheat, or lie to others)

4. Caring for other living things and environment. Regarding with the core elements of moral values, there are many experts in Kinnier et.al. who argue that moral values are all about "Golden Rules" and its implications as mentioned as follows:
a. Treating others with respect and compassion.
b. The virtues of truthfulness
c. Justice
d. Personal responsibility
e. Self-discipline
f. Courage
g. Faith

In a literary work, moral value is like a theme which is expressed in the body of a story. A moral value is something that the researcher tries to convey to the readers. It is the knowledge to be presented in a story. In general, moral can be defined as the distinction between good and bad, right and wrong with 
regard to attitudes, behavior, character, etc (Nurgiyantoro,2002:172).

\section{METHOD OF RESEARCH}

\subsection{Research Design}

In this chapter, the researcher discusses about method of research. Research is the process of collecting, analyzing, and interpreting data in order to understand a phenomenon (Leedy \& Ormrod). The research process is systematic in that defining the objective, managing the data, and communicating the findings occur within established frameworks and in accordance with existing guidelines. The frameworks and guidelines provide researchers with an indication of what to include in the research, how to perform the research, and what types of inferences are probable based on the data collected. According to Creswell (2009:3), research design is plans and the procedures for research to detailed methods of data collection and analysis.

The researcher get the data by using descriptive qualitative method. Descriptive method is a method that researches the status of human, an object, a set of condition, a system of thought, or even a class of phenomenon at the present. Qualitative research is a research procedure which produces written or spoken descriptive data of research that is possible to observe. Burhan (2008: 40-41), defines that qualitative study focuses on describing and analyzing a phenomenon, social activity, perception, belief, individual and thought. Then, this research can be categorized as library research. It is a research in which the way of collecting data taken from a variety of literatures. Literatures meant here are not only the books, but also materials taken from journal, magazines, newspapers, internet, etc.

The research design in this study can be described as an arrangement condition for collecting and analyzing data which are taken from Remember Korean drama 2016 by the author of the drama is Yoon Hyun-Ho. By using objective approach, the researcher analyzed the psychologianalysis of the main character.
Therefore, objective approach was the appropriate approach to analyze. In addition, psychoanalysis theory was used to analyze the research formulations.

\subsection{Data Collection}

Data collection methods can be defined as the process and the way of conducting research. In this study, the researcher took the data from the drama "Remember" by the author of the drama is Yoon Hyun-Ho. In collecting the data, the reseacher used the documentation method. Arikunto (2002:206), documentation is the act of looking for data which concern with matters such as note, book, newspaper, magazine, transcript, and agenda.

\subsection{Data Analysis Procedure}

The final activity in qualitative research are analyzing and interpreting the data collected and presenting the result. Ary (2005:465) states that data analysis is the process whereby researchers systematically search and arrange the data in order to increase their understanding of the data and to enable them to present what they learned to others. Therefore, there are many steps to be conducted by the researcher to analyze the data. In collecting data, the researcher used following steps:

1. Watching the drama Remember repeatedly and watching many times in last episode.

2. Understanding the content of the drama.

3. Reading and underlining script the important thing for this research.

4. Finding out the data related to research problems.

5. Finding the moral value in the drama.

\section{ANALYSIS AND FINDINGS}

\subsection{Analysis}

In this chapter the researcher is analyze the main characterization, traumatic experience and psychoanalysis of Seo Jin Woo's character in Remember. The main character is the one who play an important role in the story. 
This chapter will discuss the traumatic impact of Seo Jin Woo's character due to this incident.

\subsubsection{The Characteristic of Seo Jin-Woo}

In this section researcher analyze the characterization of Seo Jin Woo as the main character in Remember. Based on quotitation (Nurgiyantoro, 1955), characterization is a figure or people's character who is put forward in narrative work which interpret by the readers having a moral quality and certain tendency through dialogues and their behavior.

\section{Persistent}

Character Seo Jin Woo in this drama, he is a persistent person. This can be seen when he wants to clear his father's name from the false accusations made by the court for his father to cover up Nam Qyu Man's wrong doing.

In dialogue 3 - 12 (minutes 00:00:12,300 0000:01:05,780)

Seo Jin Woo : : "President Nam Gyu Man!" (driving the car)

Police : "Jin Woo, llho Group asked for permission to fly its helicopter.

Seo Jin Woo : "Got it." (on the way to Nam Gyu Man place)

Seo Jin Woo : "Are you going on a business trip abroad?"

Nam Gyu Man : "This beggar bastard, you showed up again."

Seo Jin Woo : "You're done today."

Nam Gyu Man : "Catch me if you can, bastard." "You bastards, I didn't get in yet! (helicopter left him) "

"You have to let me in! How can you leave without me?"

"Come back!"

"You bastards!"

From the above incident, it can be seen that Seo Jin Woo's persistence in catching Nam Gyu Man who wants to escape from his case. He collaborated with the police to leave Nam Gyu Man before he boarded his helicopter.

\section{Smart}

Seo Jin Woo who has a very good condition because of his condition which is
"Hyperthemesia". So that he can graduate from law school in a fast time.

In dialogue 16 - 21 (minutes 00:01:33,420 00:01:33,420)

Nam Gyu Man : "Working as an attorney and then a prosecutor, you're really busy."

Lee In Ah : : "The real murder weapon was presented."

Nam Gyu Man : "And?"

Lee In Ah : "And your fingerprints were on the wine opener."

Nam Gyu Man : "This again? But this is already over and done with. "

During the trial the Chief Judge who was in charge of the case committed fraud where he did not give Seo Jin Woo a chance to testify.

In another dialogue 170 - 181 (minutes 00:11:25,410 - 00:11:59,650)

Lee In Ah : : "I'd like to request a witness."

"He was the Chief of Staff for Nam Gyu Man and provided the weapon."

"He was called to the crime scene by Nam Gyu Man."

Lawyer Hong : "Objection !. The witness recently had a big fight with the defendant and quit his job."

"There is a high probability that the witness will commit to fight out of spite."

Lee In Ah : "The witness was already selected as a witness for Seo Jae

Hyuk's retrial and gave important testimony."

Judge : :The prosecutor's witness will not be called."

Lee In Ah : "Your Honor, the witness already gave critical ..."

Judge : :Prosecutor, if you interrupt the procedure of the trial you will be removed from the court."

\subsubsection{Traumatic Experiences}


According to DSM IV, Seo Jin Woo's conditions are considered as avoidance criteria of PTSD. People with PTSD commonly avoid some events related to traumatic experience.

1. Making attempts to avoid images, feelings, or conversation that remembering one of the traumatic events.

Seo Jin Woo didn't want to remember the events that had happened so far. She wrote down all the memories she wanted to forget in her diary and burned the book because she didn't want to remember them at all.

In dialogue 570 - 572 (minutes 00:45:59,800 00:46:28,440)

"[MEMORIES I WANT TO KEEP. MEMORIES I WANT TO FORGET.] "

"[MEMORIES I WANT TO FORGET.]" (Burns the book)

"[MEMORIES I WANT TO KEEP.]" (Keeps the book)

He burns books that contain memories he doesn't want to remember, including what happened to the father and himself. Even though he forgot what he was going through all this time. He still wants to keep good memories in the book MEMORIES I WANT TO KEEP so he can see or remember these memories.

2. Feeling fear, guilt, sadness, shame or confusion after the traumatic event occurred.

After the incident that happened to him, Seo Jin Woo felt sadness and confusion after all that had happened. Because currently Seo Jin Woo is only living alone because his father passed away. He felt that what made him a lawyer was only to clear his father's reputation. But after this incident was over he felt he did not know what to do in the future. Alzeimer's condition also got worse, so he only remembers what happened before it happened.

3. Shutting out the memories of painful periods and experiencing amnesia.

Before this case was over, Seo Jin Woo was diagnosed with Alzheimer's disease. However, Alzheimer is still early so still allows him to continue his father's case. However, after his father's case was over Alzeimer's suffering got worse. His condition with Alzheimer happened because he had a history from his father and worked too hard to remember everything so he could clear his father's name immediately. But after all was over and his Alzheimer erased the memory of the sadness he had with his father. Because the bitter memories really shook his life. In dialogue 652 - 657 (minutes 00:54:23,290 - 00:55:03,170) Lee In Ah : "Excuse me."

Seo Jin Woo : "Yes. Who ... are you?"

"If this is not the first time we've met, I'm sorry. My memory is not that good."

Lee in Ah : "No, I thought you were someone else. You look very similar to someone I know very well. "

The above conversation shows that Seo Jin Woo doesn't remember Lee In Ah, who is the woman he loves and accompanies him in handling his father's case. Lee In Ah is also a prosecutor who handles her father's case.

\subsubsection{Psychonalaysis Seo Jin Woo}

In this drama we can see the psychoanalysis of Seo Jin Woo. Based on the state of Sigmund Freud in 1896, psychoanalysis is concerned with the concept of unconsciousness. The unconsciousness can be described as a storehouse of painful experience, emotion, wound, fear, guilty desire and unresolved conflict we don't want to know about. In this drama we can see that Seo Jin Woo's psychology includes the concept of unconsciousness. Due to the pain from the conflicts he was going through, the emotions and the wounds he went through. Freud developed three personality elements: id, ego, and super-ego. As explained in the previous chapter, the three elements of personality are related. We can see that Seo Jin Woo's character belongs to the ego element. Which is where from the quote Alwisol (2014: 15), the ego develops from the id so that humans are able to handle reality, so the ego works according to the principle of reality.

Seo Jin Woo is able to fight his pain, emotions and through painful experiences by 
thinking in reality. Thinking in reality helps him clear his father's good name. If at that time he did not think in reality, maybe until whenever everyone would think that he was the son of a murderer.

\subsubsection{Moral values in Remember}

Basically, moral is the distinction between bad and good conducts which can generally be accepted in a social life. In talking about moral we can briefly say that moral is concerned with, or related to human behavior, especially the distinction between good or bad, or right and wrong behavior.

There are many moral values that we can learn from the drama. So, in this drama we don't just watch stories from dramas or see the actors. But in this drama we can learn moral values and apply them in our lives. We can use these moral values as lessons in our daily lives. Types of moral values: than oneself

1. Commitment to something greater

2. Self-respect, but with humbleness or respect to others, self-discipline, and acceptance of personal responsibility

3. Respect and caring for others

4. Caring for other living things and environment.

From the moral types above, we can see that Seo Jin Woo's character, including the first type of moral value, is Commitment to something greater than himself. Which is where in Remember Seo Jin Woo tries hard to find the truth about his father's case so that his father gets justice. He also hopes that the laws in his country can be fair to innocent people, especially to small people like himself. From this drama we can also get lessons about life from Seo Jin Woo that we must seek justice and truth in our lives. We can also learn the importance of defending and protecting our parents. In the now days many children don't care about their parents.

\subsection{Findings}

In this section researchers provide findings about the character Seo Jin Woo based on the theory above. Based on analysis the characterization above, we can know that the characterization of Seo Jin Woo is a person who is persistent, smart, kind, and loves his family. Traumatic experience of character Seo Jin Woo with his conditions are considered as avoidance criteria of PTSD based on DSM IV. Beacause in the drama Seo Jin Woo tried to forget everything about painful. Psychoanalysis of character Seo Jin Woo is based on Sigmund Freud in 1896, is the concept of unconsciousness. Character Seo Jin Woo in the drama described as a storehouse of painful experience, emotion. In this drama we also learn about moral values, types of moral values for caharcter Seo JinWoo proposed by Kinnier et.al. (2000) is commitment to something greater than oneself, Seo Jin Woo to seek truth and justice for his father's case.

\section{CONCLUSION AND SUGGESTION 5.1 Conclusions}

After analyzing Remember the writer Yoon Hyun Ho in the drama he wrote, here he wants to tell about a child's struggle for his father. Which is where he struggled to free his father from a murder charge. This drama focuses on the intelligence of the main character, legal injustice, and the psychology of the main character.

Traumatic experience is a short event that forces our mind to rethink memory in the past. Most of the people who have traumatic experience tend to show a post- traumatic stress disorder. The researcher found that Seo Jin Woo the main character of the drama, is suffered from Post-Traumatic Stress Disorder. The writer concludes that because Seo Jin Woo shows some PTSD symptoms. First, Seo Jin Woo Making attempts to avoid feeling that remembering one of the traumatic events, he burn his book "Memories I want to forget". Second Seo Jin Woo feeling sadness and confusion after the traumatic event occurred because currently Seo Jin Woo is only living alone because his father passed away. Third, Seo Jin Woo tried to forget the painful memories he get Alzheimer.

Seo Jin Woo's psychoanalysis includes unconsciousness where he feels fear and pain for what happened to him and his father. The 
personality of Seo Jin Woo is a super-ego where he is able to think about reality in order to be able to help his father with this goal.

The moral values can be taken from this drama is Commitment to something greater

\section{REFERENCES}

Abdul Mufied Yasin, 2016, Post-Traumatic Stress Disorder Suffered by Katie in Nicholas in sparks' safe heaven, Universitas Islam Negri Maulana Malik Ibrahim Malang.

Abrams, M. H. 1981. A Glossary of Literary Terms (5th Ed). New York: Holt, Rinehart and Winston.

Allen, Jon G. 1995. Coping with Trauma: A Guide to Self-Understanding. Washington, DC: American Psychiatric Press.

Alwisol. (2014). Psikologi Kepribadian (edisi revisi). Malang: UMM Press.

Association, A. P. (1994). Diagnostic and Statistical Manual of Mental Disorders 4th edition. Washington DC: The American Psychiatric Association.

Cicilia Damayanti, 2015, Psikologi Sastra Dalam Novel The Book Of Proper Names Karya Amelié Nothomb, Jakarta, Universitas Indraprasta PGRI.

Elizabeth B. Hurlock. 1972. Child Development Six Edition. Mc Graw Hill Book Company

Esther Lombardi, Updated January 31, 2020, What Literature Can Teach Us (internet). Retrieved from https://www.thoughtco.com/what-isliterature-740531.

Feist, Jess dan Gregory J. Feist. 2010. Teori Kepribadian. Jakarta: Selemba Humanika

Freud, S. (1920) A General Introduction to Psychoanalysis. Retrieved from < https://eduardolbm.files.wordpress.co $\mathrm{m} / 2014 / 10 / a-g e n e r a l-i n t r o d u c t i o n-t o-$ psychoanalysis-sigmund-freud.pdf Freud, Sigmund. 1958. A General Introduction to Psychoanalysis. New York: Permabooks MD, LL.D. than oneself. In Se Jin Woo's character, his moral value is that truth and justice must be sought and fought for, so that the law does not side with the ruling.

Giovanny Mario, 2012, A Psychoanalysis On The Main Character And The Author of Sherlock Holmes: A Study In Scarlet, Jakarta, Bina Nusantara University

Hawkes, Terence. 2003. Structuralism and Semiotics (2nd Ed). New York: Routledge.

Heller, S. (2005). Freud A to Z. Canada: John Wiley \& Sons, Inc.

Kinnier, Richard T, Kernes, Jerry L. and Dautheribes, Therese M. 2000. "A short list of universal moral values: Counseling and values". Vol. 45, No.1.

Marshall, G. N. (2000). A Review of the Scientific Literature As It Pertains to Gulf War Illnesses: Volume 4: Stress. Retrieved from https://www.rand.org/content/dam/ra nd/pubs/monograph_reports/MR1018z 4- 1/MR1018.4.chap2.pdf

McNally RJ; Bryant RA \& Ehlers A (2003). "Does early psychological intervention promote recovery from posttraumatic stress?". Psychological Science in the Public Interest 4 (2): 45. doi:10.1111/1529-1006.01421

Minderop, 2016, Karya, Metode, Teori, dan Contoh Kasus, Jakarta: Yayasan Pustaka Obor Indonesia Edisi 2.

M. Afifulloh, 2019, A Psychological Analysis Of The Main Character In Marsiraji Thahir's Kabar Bunga, Universitas Bangka Belitung, Lire Journal

Nurgiyantoro, B. 1995. Teori Pengkajian Fiksi. Yogyakarta: Gadjah Mada University.

Pearlman, Laurie Anne, and Karen W. 1995. Saakvitne. Trauma and the Therapist. New York: Norton. 